Original Article

\title{
Functional Imbalance between Th17, Th1, and Treg Cells in A. actinomyctemcomi- tans -Accelerated Atherosclerosis
}

\author{
Ru Jia, ${ }^{1}$ Tomoko Kurita-Ochiai, ${ }^{2}$ Tomomi Hashizume-Takizawa, ${ }^{2}$ Ryoki Kobayashi, ${ }^{2}$ \\ and Masafumi Yamamoto ${ }^{2}$
}

${ }^{1}$ Nihon University Graduate School of Dentistry at Matsudo, Microbiology and Immunology, Matsudo, Chiba 271-8587, Japan

${ }^{2}$ Department of Oral Immunology, Nihon University School of Dentistry at Matsudo, Matsudo, Chiba 271-8587, Japan

\section{Article History}

Received 3 April 2013

Accepted 16 April 2013

\section{Keywords :}

periodontopathic bacteria, periodontal disease, atherosclerosis, $\mathrm{T}$ helper cells, regulatory $\mathrm{T}$ cells

\begin{abstract}
Recent studies have shown an association between periodontal disease and cardiovascular disease. We previously reported that Aggregatibacter actinomyctemcomitans $(A a)$ bacteremia accelerated atherosclerosis in apolipoprotein E-deficient spontaneously hyperlipidemic $\left(A p o e^{\mathrm{shl}}\right.$ ) mice. Atherosclerosis is a chronic inflammatory disease regulated by $\mathrm{T}$ lymphocyte subsets. In this study, we investigated whether the functional imbalance between Th17, Th1, and regulatory T (Treg) cells, existed in $A a$-challenged Apoe $^{\text {shl }}$ mice. The mice were intravenously treated with live Aa HK1651 or vehicles. Histomorphometric features of atheromatous lesions, IL- $17^{+} \mathrm{CD} 4^{+}, \mathrm{IFN}-\mathrm{g}^{+} \mathrm{CD} 4^{+}$, and Foxp $3^{+} \mathrm{CD}^{+}$cell frequencies, serum IL-17, IL-6, TGF- $\beta$, IFN- $\gamma$, and IL-10 levels, and gene expression of Th17-related molecules were examined. Aa challenge induced a Th17/Th1 shift in Apoe ${ }^{\text {shl }}$ mice. Aa-challenged splenic Th1 and Th17 cells greatly increased in contrast with reduction in Treg cells after their transient increase at 13 weeks. Serum cytokine levels of IL-6 were significantly enhanced during $A a$-challenge. Similarly, gene expression of differentiation factors (IL-6, IL-17RA and IL-21), growth/stabilization factor (IL-23), and transcription factor (STAT3) involved in the development of Th17 cells, as well as Th1-related IFN- $\gamma$ were also stimulated in $A a$-challenged mice. These results suggest that Th17/Th1/Treg imbalance affect the progression of $A a$ - accelerated atherosclerosis.
\end{abstract}

\section{Introduction}

Atherosclerosis is a chronic inflammatory disease that involves $\mathrm{T}$ lymphocytes, particularly $\mathrm{CD}^{+} \mathrm{T}$ cells $(1,2)$. When these cells infiltrate into the plaques, they can secrete a number of inflammatory cytokines and participate in the various phases of immune and inflammatory responses in the pathogenesis of atherosclerosis. The up-regulation of $\mathrm{T}$ helper cell 1 (Th1) response has been found in the local atherosclerotic lesions and circulating lymphocytes in atherosclerotic animal models and patients with acute coronary syndrome, suggesting that Th1/Th2 imbalance plays an important role in the development of atherosclerosis and plaque rupture (3-4).

Correspondence to :

Tomoko Kurita-Ochiai

E-mail : ochiai.tomoko@nihon-u.ac.jp
Furtherore, recent study demonstrated that the peripheral Th17/Treg imbalance also existed in patients with acute coronary syndrome, suggesting a potential role of Th17/Treg imbalance in plaque destabilization(5). De Boer et al. also reported that the frequency of naturally occurring Treg cells decreased in all developmental stages of human atherosclerotic lesions (6). Th17 cells have been reported as a new subpopulation of $\mathrm{CD}^{+} \mathrm{T}$ cells (7), and their key regulator for Th17-cell lineage differentiation is the retinoic acid-related receptor $\gamma t$ ( $\mathrm{ROR} \gamma \mathrm{t}$ ) (8). Th17 cells produce the signature cytokine interleukin-17 (IL-17) and participate in the induction of inflammation $(9,10)$. IL-17 and Th17 cells have been implicated in the pathogenesis of many chronic infectious disease caused by microbial pathogens $(11,12)$. The increase of Th17 cells in chronic periodontal patients and by Porphyromonas gingivalis exposure to peripheral 
blood mononuclear cells in vitro were also recognized (13, 14).

We have previously shown that Aggregatibacter actinomyctemcomitans $(A a)$ bacteremia accelerated the progression of atherosclerosis through induction of inflammation and promotion of lipid oxidation in apolipoprotein $\mathrm{E}$ (apoE) -deficient spontaneously hyperlipidemic (KORApoe $\left.^{\text {shl }}\right)$ mice $(15,16)$. Periodontal bacteria such as $A a$ and their components may have direct access to the circulation through bleeding periodontal pockets. $A a$ has been detected in human atherosclerotic plaques $(17,18,19)$. However, little is known about how $A a$ influences $\mathrm{T}$ cell function in progression of atherosclerosis. Therefore, in this study, we investigated Th1/Th17/Treg distribution at different levels including cell frequencies in spleen, related serum cytokine secretion and related molecule-specific mRNA expression in spleen of Apoe ${ }^{\text {shl }}$ mice.

\section{Materials and Methods}

Bacterial strains

Aa HK1651 (ATCC 700685) was grown in Todd-Hewitt broth (BBL, Cockeysville, MD, USA) supplemented with 1\% yeast extract (Difco Laboratories, Detroit, MI, USA) at $37^{\circ} \mathrm{C}$ in $5 \% \mathrm{CO}_{2}$ for 3-4 days until it reached an $\mathrm{OD}_{540}$ of 0.55 , which corresponds to $1 \times 10^{9} \mathrm{CUF} / \mathrm{mL}$. The cultured cells were then centrifuged at $8000 \mathrm{~g}$ for $20 \mathrm{~min}$ at $4^{\circ} \mathrm{C}$ and diluted in phosphate-buffered saline (PBS) for intravenous (i.v.) infection.

Mice

Ten-week-old female KOR-Apoe ${ }^{\text {shl }}$ mice (20) obtained from Japan SLC Inc. were given regular chow diet and water $a d$ libitum. The institutional Animal Care and Use Committee of Nihon University approved all the animal protocols. After 1 week, the mice were randomly divided into eight groups, and used for experiments. The mice were treated i.v. with $0.1 \mathrm{~mL}$ of live $A a\left(10^{8} \mathrm{CFU} /\right.$ mouse $)$ or PBS three times a week for 1, 2, 3 weeks. Mice were killed at 12, 13, 14 and 15 weeks ( $n=6$ per group) after injection. Blood samples were collected in heparinized syringes from the orbital veins of mice anesthetized with Isozol (Nichi Iko, Toyama, Japan).

\section{Quantification of atherosclerotic lesion area}

The heart and aortic tree were perfused through the left ventricle with ice-cold $0.9 \%$ saline for $10 \mathrm{~min}$. The heart was then carefully dissected and removed. The upper half of the heart, which contains the aortic origin, was separated and embedded in Tissue-Tek (Fisher Scientific, Newark, DE, USA) OCT compound in cryomolds, and frozen sections of the proximal aorta were prepared as described previously (15). Briefly, $6 \mathrm{~mm}$-thick sections pre mouse were stained with Oil Red O to visualize neutral lipid and counterstained with hematoxylin. Total lesion area per slide and percentage of the aortic lumen occupied by lesions per section were calculated using image analysis software (Lumina Vision, Mitani Co., Fukui, Japan). The values of 15 sections per animal were averaged and expressed as the mean lesion area and percentage of the lumen of the proximal aorta occupied by lesions per section per animal.

\section{Flowcytometric analysis of Th17, Th1, and Treg cells}

Single-cell suspensions were obtained from the spleen of mice treated with $A a$ or PBS for 1, 2 and 3 weeks. For intracellular staining, the cell suspensions were stimulated for $5 \mathrm{~h}$ with $50 \mathrm{ng} / \mathrm{ml}$ phorbol 12-myristate 13-acetate (PMA: Sigma-Aldrich, St. Louis, MO, USA), 1mM ionomycin (Sigma-Aldrich) and $500 \mathrm{ng} / \mathrm{ml}$ monensin (Sigma-Aldrich). For surface staining of cells, a fluorescein isothiocyanate (FITC) -conjugated anti-mouse CD4 monoclonal antibody (Becton Dickingson) was used. After surface staining, fixation and permeabilization, cells were stained with phycoerythrin (PE) anti-mouse-IL-17 for Th17 detection, $\mathrm{PE}$ anti-mouse interferon- $\gamma$ (IFN- $\gamma$ ) for Th1 detection, or PE anti-mouse forkhead/singed helix transcription factor (Foxp3) for Treg cell detection according to the manufacturer's instructions (all of the Abs were from eBioscience, San Diego, CA). Isotype controls were given to enable correct compensation and confirm antibody specificity. Stained cells were analyzed by flow cytometric analysis using a FACScan cytometer equipped with CellQuest software (BD Bioscience Pharmingen).

\section{Serum analysis}

Serum was isolated from blood by centrifugation at $2500 \mathrm{~g}$ for $20 \mathrm{~min}$ after clotting at room temperature. The concentration of IL-17, IL-6, transforming growth factor-b (TGF- $\beta$, IFN- $\gamma$, and IL-10 in serum was measured by enzyme-linked immunosorbent assay (ELISA) following the manufacture's instructions (ELISA kits for IL-17 and TGF- $\beta$, R\&D Systems, Minneapolis, MN; ELISA kits for IFN$\gamma$, IL-6 and IL-10, Thermo Scientific, Rockford, IL). 
(A)

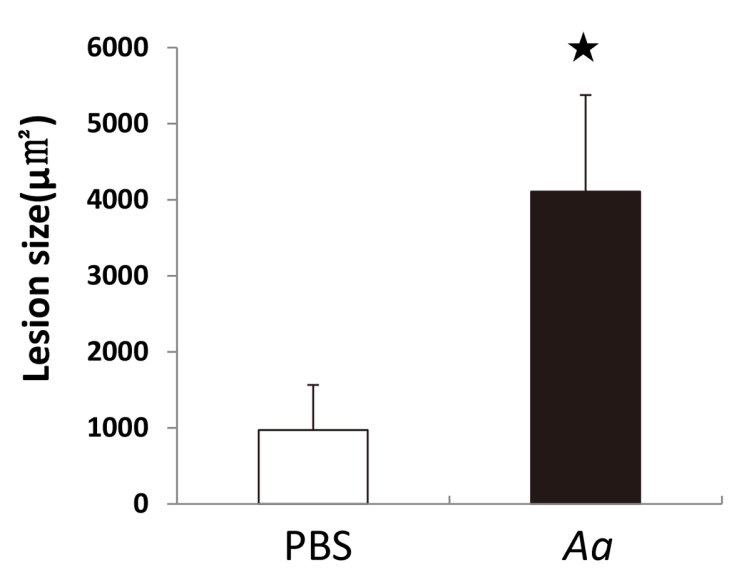

(C)

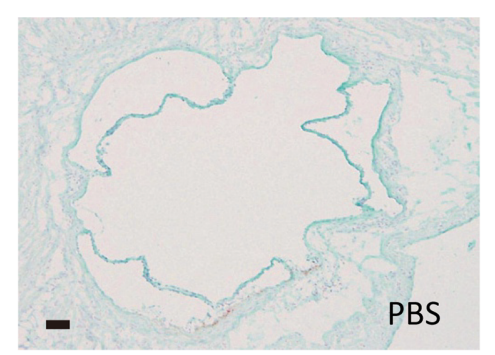

(B)


Fig.1 Atherosclerotic plaque formation in the aortic sinuses of Apoe ${ }^{\text {shl }}$ mice intravenously challenged with live $A a$. The results of histomorphometric analysis of the mean lesion area (A) and the percentage of the aortic sinus occupied by lesions (B) are shown at 15 weeks. The data are given as the means \pm SD of 6 mice. ${ }^{\star} P<0.05$ compared with control mice. (C) Oil red O-stained cryosections of the proximal aorta. The arrow indicates a typical lipid-rich atherosclerotic area stained with oil red O. Scale bars $=50 \mu \mathrm{m}$.

Analysis of gene expression by quantitative real-time $R T$ PCR

Total RNA purified from the aorta $(n=6$ per group $)$ was reverse transcribed with oligo $(\mathrm{dT})$ primers using SuperScript II reverse transcriptase (Invitrogen, Carlsbad, CA, USA) to generate cDNA. Quantitative real-time RTPCR analyses were performed using a Thermal Cycler Dice real-time PCR system (Takara, Shiga, Japan) in accordance with the manufacturer's protocol. The reactions (final volume, $25 \mu \mathrm{L}$ ) contained $30 \mathrm{ng}$ of reverse-transcribed RNA, 12.5 $\mu \mathrm{L}$ of $2 \times$ SYBR Green PCR Master Mix（Takara） and primers (concentration, $100 \mathrm{nM}$ each). The primers are shown in Table 1. The PCR program comprised an initial denaturation step $\left(95^{\circ} \mathrm{C}\right.$ for $\left.10 \mathrm{~min}\right)$, followed by 40 cycles at $95^{\circ} \mathrm{C}$ for $15 \mathrm{~s}, 55^{\circ} \mathrm{C}$ for $25 \mathrm{~s}$, and $60^{\circ} \mathrm{C}$ for $35 \mathrm{~s}$. Each gene was tested in triplicate. Target RNA levels were normalized to GAPDH mRNA.

\section{Statistical analysis}

The data are presented as means \pm standard deviation
(SD). Differences between the groups were considered significant at $p<0.05$ using an unpaired Student $t$ test.

\section{Results}

Atherosclerotic plaque formation in aortic sinuses

Histomorphometric analysis revealed a significant increase in atherosclerotic plaque accumulation in $A a$ challenged mice compared to sham-treated mice, with the percentage of the total lumen of the proximal aorta occupied by lesions showing the same pattern (Fig. $1 \mathrm{~A}$ and C: $4108 \pm$ $1268 \mathrm{~mm}^{2}$ for $A a$-challenged mice vs. $972 \pm 593$ for shamtreated mice; $P<0.05$ ) (Fig. $1 \mathrm{~B}$ and C: $3.28 \pm 0.85 \%$ for Aa-challenged mice vs. $0.90 \pm 0.34$ for sham-treated mice; $P<0.05$ ).

Flow cytometry analysis of Th17/Th1/Treg balance in splenic cells

The levels of splenic $\mathrm{CD} 4^{+} \mathrm{IL}-17^{+}$cells were significantly higher in $A a$-challenged mice than those in their wild-type littermates at all time points, moreover it achieved the 




Fig.2 The percentage of Th17, Th1 and Treg cells in total splenocytes (A) and CD4 ${ }^{+}$splenocytes (B) from Apoe ${ }^{\text {shl }}$ mice after $A a$ challenge. At 12, 13 and 14 weeks, spleens were removed, single cell suspensions were prepared, and the cells stained with FITC-CD4, PE-IL-17, PE-IFN- $\gamma$, and PE-Foxp3 Abs were analyzed by flow cytometry. (A) The percentage of positive cells was shown in each panel. (B) Data were presented as the means \pm SD $(n=6)$.

maximal value at 14 weeks time dependently (Fig. 2). Consistent with IL- $17^{+}$cells, the levels of $\mathrm{CD}^{+} \mathrm{IFN}-\gamma^{+}$cells in the spleen of $A a$-challenged mice were also higher compared with age-matched control, and achieved the maximal value at 14 weeks. Although the levels of $\mathrm{CD}^{+}$ $\mathrm{Foxp}^{+}$cells were also reached the maximum at 13 weeks, they obviously decreased at 14 weeks. This finding suggests that Aa-challenge time-dependently increases splenic Th1 and Th17 cell populations in contrast with reduction in Treg cells after their transient increase at 13 weeks.

\section{Serum IL-17, IFN- $\gamma, I L-6, I L-10$ and TGF- $\beta$ levels}

$A a$-challenge significantly increased serum IL-6 level (Fig. 3: $206.35 \pm 8.84 \mathrm{pg} / \mathrm{ml}$ vs. $104.15 \pm 5.87 \mathrm{p}<0.05)$ compared with PBS inoculated group. IL-17, IFN- $\gamma$ and IL-10 levels were also higher in $A a$-challenged mice than those in contol group. (Fig.3: IL-17, 1861.67 $\pm 890.15 \mathrm{pg} / \mathrm{mL}$ vs.1248 $\pm 530.42 \mathrm{pg} / \mathrm{mL}$, IFN- $\gamma, 1300.33 \pm 458.12 \mathrm{pg} / \mathrm{mL}$ vs. 1075.56 $\pm 230.1 \mathrm{pg} / \mathrm{mL}$, IL-10, $312.67 \pm 105.2 \mathrm{pg} / \mathrm{mL}$ vs. $206.23 \pm$ $89.34 \mathrm{pg} / \mathrm{mL}$ ), although this did not reach statistical significance. Furthermore, we observed no significant difference in the production of TGF- $\beta$.

Th17, Th1 and Treg related molecules-specific mRNA expression in spleen

To examine the involvement of Th17, Th1, and Tregrelated molecules in atherosclerosis enhanced by $A a$ challenge, we analyzed the kinetics of their mRNA expression in the spleen of mice at 15 weeks by real-time RT-PCR. The analysis showed that $A a$-challenge induced a significant increase in IL-6, IL-17RA, IL-21, IL-23 and IFN- $\gamma$ mRNA levels $(p<0.05)$ and slight increase in TGF- $\beta$, STAT3, STAT4 and Foxp3 mRNA levels in spleen (Fig. 4). However, there was no significant difference in the expression of T-bet-specific mRNA between $A a$-challenged and control mice.

\section{Discussion}

The Th1/Th17/Treg balance controls inflammation and may be important in atherosclerosis. To investigate whether 


\section{IL-17}

$\mathrm{pg} / \mathrm{mL}$
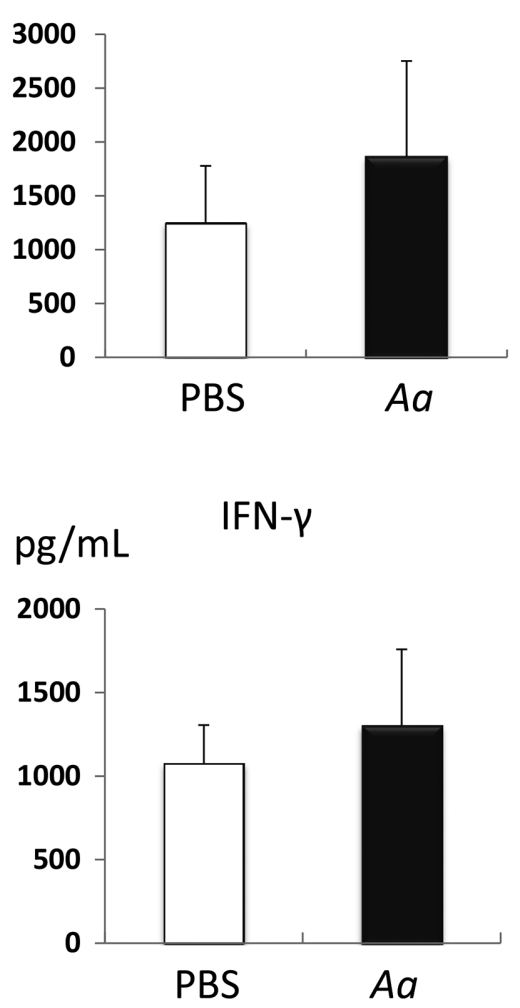

IL-6

$\mathrm{pg} / \mathrm{mL}$

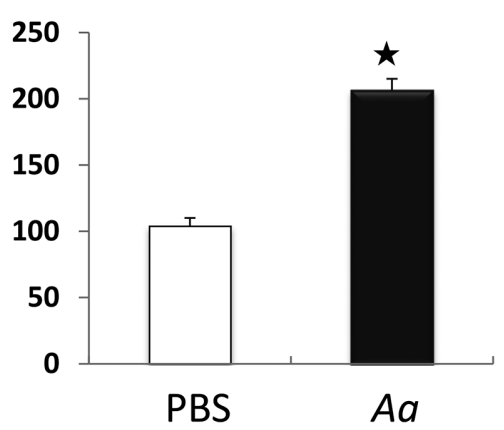

IL-10

$\mathrm{pg} / \mathrm{mL}$



Fig.3 Serum IL-17, IL-6, TGF- $\beta$, IFN- $\gamma$ and IL-10 levels in 15-week Apoe ${ }^{\text {shl }}$ mice following challenge with $A a$. Values represent means $\pm \mathrm{SD}(\mathrm{n}=6) .{ }^{\star} P<0.05$ compared with control mice.
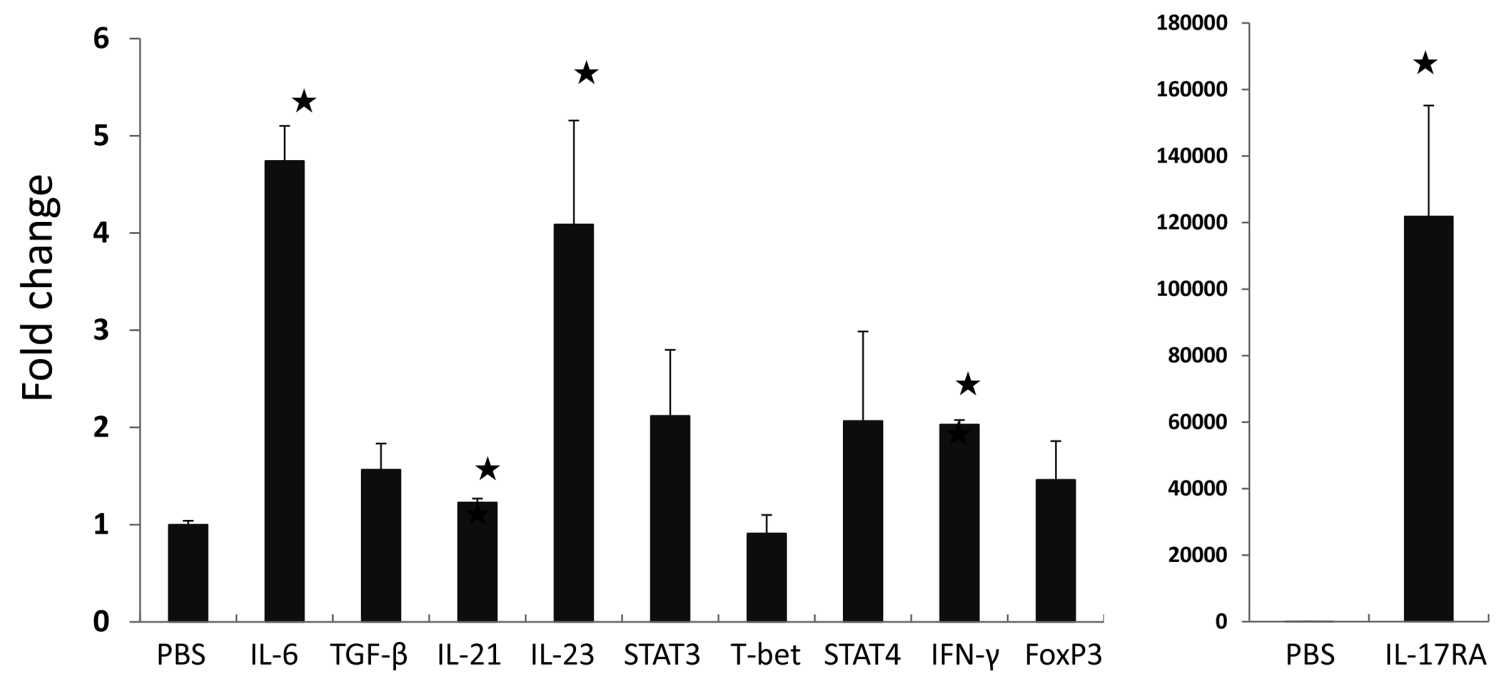

Fig.4 Th17-, Th1- and Treg-related gene expression in splenocytes from 15-week Apoe ${ }^{\text {shl }}$ mice following challenge with $A a$. Relative mRNA levels were obtained after normalization to GAPDH $(n=6)$ by realtime RT-PCR. The data are expressed as fold increases in mRNA level compared with the PBS-treated negative control. Values represent means $\pm \mathrm{SD}(\mathrm{n}=6) .{ }^{\star} P<0.05$ compared with control mice. 
Table 1 Primers sequences used for the real-time RT-PCR

\begin{tabular}{lll}
\multicolumn{1}{c}{ Primer } & \multicolumn{1}{c}{ Forward } & \multicolumn{1}{c}{ Reverse } \\
\hline GAPDH & TGTGTCCGTCGTGGATCTGA & TTGCTGTTGAAGTCGCAGGAG \\
IL-6 & CCACTTCACAAGTCGGAGGCTTA & GCAAGTGCATCATCGTGTTCATAC \\
TGF- $\beta$ & GTGTGGAGCAACATGTGGAACTCTA & TTGGTTCAGCCACTGCCGTA \\
IL-17RA & CCGACCTCTTCAACATCACCTC & CCACTCCTGGAACCTAAGCACA \\
IL-21 & AATTCAATGCAGCACAGGCTAAGA & GTTCCCACCCACAGTGAACAATAA \\
IL-23 & ACATGCACCAGCGGGACATA & CTTTGAAGATGTCAGAGTCAAGCAG \\
STAT3 & CCTGGGTTAACCACCCATAGTGAG & AGTGCAGTGGCCAGAACACAAG \\
T-bet & TTCCCATTCCTGTCCTTCAC & CCTCTGGCTCTGCATCATTC \\
STAT4 & GCATGGGCATCCATCATTTG & AATTGCCAGCTCATCACTTCCAG \\
IFN- $\gamma$ & CGGCACAGTCATTGAAAGCCTA & GTTGCTGATGGCCTGATTGTC \\
FoxP3 & AGTGCCTGTGTCCTCAATGGTC & AGGGCCAGCATAGGTGCAAG \\
& & \\
\hline
\end{tabular}

the Th1/Th17/Treg functional imbalance existed during $A a$-accelerated atherogenesis in mice, we detected Th1/ Th17/Treg distribution comparatively between $A a$-challenged atherosclerosis-prone hyperlipidemic Apoe ${ }^{\text {shl }}$ mice and sham-treated mice. In this study, we demonstratd that the percentages of Th17 and Th1 cells was time-depedently increased in the spleen of $A a$-challenged mice compared with that of PBS-treated mice. In contrast, the ratio of Treg cells in $A a$-challenged mice was decreased in 14 weeks after the transient increase in 13 weeks although the value was higher than PBS-treated control.

$A a$-challenge significantly increased in splenic IL-17 ${ }^{+}$ $\mathrm{CD}^{+}{ }^{+} \mathrm{T}$ cell population, Th-17-related serum cytokines (IL17 and IL-6), and Th17-related molecule expressions (IL-6, IL-17RA, IL-21 and IL-23) in spleen. Aa-challenge also increased $\mathrm{IFN}-\gamma^{+} \mathrm{CD} 4^{+} \mathrm{T}$ cell population in FACS analysis associated with increase in serum IFN- $\gamma$ and Th1-related molecule expression (STAT4 and IFN- $\gamma$ ) except for T-bet, although the difference was not statistically significant. Although splenic Treg cell ratio immediately declined after transient increase at 13 weeks, the Treg ratio higher than control was maintained even after bacteria-challenged. Indeed, serum IL-10 level and splenic Foxp3 expression was also higher in $A a$-challenged mice than control mice. These results suggest that the increase in Th1 and Th17 cells rather than the population of Treg cells, is related to exacerbation of arteriosclerosis in $A a$-challenged mice. Recently, important role of Th1 and Th17 cells in atherosclerosis has reported (21). Circulating IL-17 and IFN$\gamma$ were increased in a subset of patients with coronary atherosclerosis (22). The majority of pathogenic $\mathrm{T}$ cells in atherosclerosis was Th1 phenotype to date, producing proinflammatory mediators, such as IFN- $\gamma$ and activating macrophages $(23,24)$. Th1-type immune responses are injurious to the atherosclerotic process. IFN- $\gamma$ inhibits the synthesis of collagen by the vascular smooth muscle cells, incubating the unstable plaque with thin fibrous cap. It also activates monocytes/macrophages and dendritic cells, maintaining the pathogenic Th1 response (25). Deficiency in IFN- $\gamma$ or in its receptor significantly reduces lesion development and enhances plaque collagen content, whereas exogenous administration of IFN- $\gamma$ enhances lesion development $(26,27)$. Recently, IL-17 producing Th17 cells are shown to be an important effector cells in autoimmune and inflammatory disease in mice (28). Although the precise role of IL-17 in atherosclerosis remains controversial, recent studies have begun to provide more direct evidence that IL17 seems to be predominantly proatherogenic (29). A proof of IL-17 proatherogenic effect is the observation that $\mathrm{CD} 4^{+}$ $\mathrm{T}$ cells isolated from atherosclerotic coronary vessels express both IL-17 and IFN- $\gamma(30)$. Furthermore, increased frequencies of circulating Th17 cells and Th17-associated cytokines correlated to the severity and progression of carotid artery plaques (31).

In addition to Th17 cells, Treg cells are also involved in the regulation of the immuno-inflammatory responses in atherosclerosis. They have anti-inflammatory, immunoregulatory, and suppressive properties and are involved in the modulation of adaptive immune responses, being able to suppress effector $\mathrm{CD}^{+}$and $\mathrm{CD}^{+} \mathrm{T}$ cells and to induce tolerance $(32,33)$. In this experiment, since the Treg cell was maintaining the ratio higher than control, it is considered that Treg cells do not to participate in exacerbation or suppression of arteriosclerosis directly. In contrast, it has been reported that the conversion of $\mathrm{CD}^{+}$ $\mathrm{CD}^{2} 5^{+}$regulatory T-cells (Tregs) into T-cells with a Th17 
phenotype occurs by appropriate inflammatory stimuli (34, 35). Furthermore, the presence of $\mathrm{IL}-17^{+} / \mathrm{Foxp}^{+}$doublepositive cells was also recognized in periodontitis (36). Therefore, the increase in the Foxp3 expression in spleen cell of $A a$-challenged mice and the increase in $\mathrm{CD}^{+} \mathrm{Foxp}^{+}$ $\mathrm{T}$ cells for 13 weeks may be the Treg cells before conversion to Th17 cells.

Recently, it was shown that innate immune signal is deeply concerned with Th17 cell differentiation(37). NOD1 and NOD2 are required to induce early Th17 responses to bacterial pathogens (38). Since $A a$-challenge significantly increased in NOD1 and NOD2 mRNA expression in Apoe ${ }^{\text {shl }}$ mice (16), the recognition of innate and inflammatory signals by dendritic cells via pattern recognition receptor, may activate the intracellular pathways involved in $\mathrm{CD}^{+} \mathrm{T}$ cell differentiation into Th17 cells.

In conclusion, our results demonstrated that Th17/Th1/ Treg imbalance existed in $A a$-challenged mice may be contributed to the aggravation of atherosclerosis caused by this parasite. Furthermore, the increase in Th17 by $A a$ challenge may play a central role in both the induction and persistence of chronic inflammation in part by producing proinflammatory cytokine IL-17.

\section{Acknowledgments}

This study was supported by Grants-in-Aid for scientific research (22390398) from the Japan Society for the Promotion of Science, and by the "Strategic Research Base Development” Program (Japan (MEXT), 2010-2014 (S1001024)) for Private Universities from the Ministry of Education, Culture, Sports, Science and Technology, Japan.

Declaration of interest: The authors report no conflicts of interest. The authors alone are responsible for the content and writing of the paper.

\section{References}

1. Libby P: Inflammation in atherosclerosis. Nature 420: 868874, 2002.

2. Hansson GK: Inflammation, atherosclerosis, and coronary artery disease. N Engl J Med, 352: 1685-1695, 2005.

3. Methe H, Brunner S, Wiegand D, Nabauer M, Koglin J, Edelman ER: Enhanced T-helper-1 lymphocyte activation patterns in acute coronary syndoromes. J Am Coll Cardiol, 45: 1939-1945, 2005.

4. Cheng X, Liao YH, Ge H, Li B, Zhang J, Yuan J, Wang M, Liu Y, Guo Z, Chen J, Zhang J, Zhang L: TH1/TH2 functional imbalance after acute myocardial infarction: coronary arterial inflammation or myocardial inflammation. J Clin Immunol, 25: 246-253, 2005.

5. Cheng X, Yu X, Ding YJ, Fu QQ, Xie JJ, Tang TT, Yao R, Chen Y, Liao YH: The Th17/Treg imbalance in patients with acute coronary syndrome. Clin Immunol, 127: 89-97, 2008.

6. de Boer OJ, van der Meer JJ. Teeling P, vander Loos CM, van der Wal AC: Low numbers of FOXP3 positive regulatory $\mathrm{T}$ cells are present in all developmental stages of human atherosclerotic lesions. PLos ONE, 2 (8): e779: 1-7, 2007.

7. Harringion LE, Hatton RD, Mangan PR, Turner H, Murphy TL, Murphy KM, Weaver CT: Interleukin 17-producing CD4 ${ }^{+}$ effector $\mathrm{T}$ cells develop via a lineage distinct from the $\mathrm{T}$ helper type 1 and 2 lineages. Nat Immunol, 6: 1123-1132, 2005.

8. McGeachy MJ, Gua DJ: Th17 cell differentiation: the long and winding road. Immunity, 28: 445-453, 2008.

9. Peck A, Mellins ED: Plasticity of T-cell phenotype and function: the $\mathrm{T}$ helper type 17 example. Immunology, 129: $147-153,2009$.

10. Crome SQ, Wang AY, Leving MK: Translational mini-review scries on Th17 cells: function and regulation of human $\mathrm{T}$ helper 17 cells in health and disease. Clin Exp Immunol, 159: 109-119, 2010.

11. McGeachy MJ, McSorley SJ: Microbial-induced Th17: Superhero or Supervillain? J Immunol, 189: 3285-3291, 2012.

12. Maddur MS, Miossec P, Kaveri SV, Bayry J: Biology, pathogenesis of autoimmune and inflammatory disease, and therapeutic strategies. Am J Pathol, 181: 8-18, 2012.

13. Adibrad M, Deyhimi P, Ganjalikhani HM, Behfarnia P, Shajabuei M, Rafiee L: Signs of the presence of Th17 cells in chronic periodontal disease. J Periodont Res, 47: 525-531, 2012.

14. Moutsopoulos NM, Kling HM, Angelov N, Jin W, Palmer RJ, Nares S, Osorio M, Wahl SM: Porphyromonas gingivalis promotes Th17 inducing pathways in chronic periodontitis. J Autoimmun, 39: 294-303, 2012.

15. Zhang T, Kurita-Ochiai T, Hashizume T, Du Y, Oguchi S, Yamamoto M: Aggregatibacter actinomycetmcomitans accelerates atherosclerosis with an increase in atherogenic factors in spontaneously hyperlipidemic mice. FEMS Immunol Med Microbiol, 59: 143-151, 2010.

16. Jia R, Kurita-Ochiai T, Oguchi S, Yamamoto M: Periodontal Pathogen Accelerates Lipid Peroxidation and Atherosclerosis. J Dent Res, 92: 247-252, 2013.

17. Kozarov EV, Dorn BR, Shelburne CE, Dunn WA Jr., Progulske-Fox A: Human atherosclerotic plaque contains viable invasive Actinobacillus actinomycetemcomitans and Porphyromonas gingivalis. Arterioscl Throm Vasc Biol, 25: e17-e18, 2005.

18. Nakano K, Inaba H, Nomura R, Nemoto H, Takeda M, 
Yoshioka H, Matsue H, Takahashi T, Taniguchi K, Amano A, Ooshima T: Detection of cariogenic Streptococcus mutans in extirpated heart valve and atheromatous plaque specimens. J Clin Microbiol, 44: 3313-3317, 2006.

19. Figuero E, Sanchez-Beltran M, Cuesta-Frechoso S, Tejerina JM, del Castro JA, Gutierrez JM, Gutiérrez JM, Herrera D, Sanz M: Detection of periodontal bacteria in atheromatous plaque by nested polymerase chain reaction. J Periodontol, 82 : 1469-1477, 2011.

20. Matsushima Y, Sakurai T, Ohoka A, Ohnuki T, Tada N, Asoh Y, Tachibana M: Four strains of spontaneously hyperlipidemic (SHL) mice: phenotypic distinctions determined by genetic backgrounds. J Atheroscler Thromb, 8: 71-79, 2001.

21. Taleb S, Tedgui A, Mallat Z: Adaptive $T$ cell immune response and atherogenesis. Curr Opin Pharmacol, 10: 197202, 2010.

22. Eid RE, Rao DA, Zhou J, Lo SF, Ranjbaran H, Gallo A, Sokol SI, Pfau S, Pober JS, Tellides G: Interleukin-17 and interferongamma are produced concomitantly by human coronary artery-infiltrating $\mathrm{T}$ cells and act synergistically on vascular smoogh muscle cells. Circulation, 119: 1424-1432, 2009.

23. Ait-Oufella H, Taleb S, Mallat Z, Tedgui A: Recent advances on the role of cytokines in atherosclerosis. Atheroscler, Thromb, Vasc Biol, 31: 969-979, 2011.

24. George J, Schwartzenberg S, Medvedovsky D: Regulatory T cells and IL-10 levels are reduced in patients with vulnerable coronary plaques. Atherosclerosis, 222: 519-523, 2012.

25. Tedgui A, Mallar Z: Cytokines in atherosclerosis: pathogenic and regulatory patyways. Physiol Rev, 86: 515-581, 2006.

26. Gupta S, Pablo AM, Jiang XC, Wang N, Tall AR, Schindler C: IFN-gamma, potenticates atherosclerosis in ApoE knock-out mice. J Clinical Invest, 99: 2752-2761, 1997.

27. Whitman SC, Ravisankar P, Elam H, Daugherty A: Exogenous interferon-g enhances atherosclerosis in apolipoprotein $\mathrm{E}$-/mice. Am J Pathol, 157: 1819-1824, 2000.

28. Miossec P: IL-17 and Th17 cells in human inflammatory diseases. Microbes Infect, 11: 625-630, 2009.

29. Chen S, Crother TR, Arditi M: Emerging role of IL-17 in atherosclerosis. Innate Immunity, 2: 325-333, 2010.

30. Eid RE, Rao DA, Zhou J: Interleukin-17 and interferon-g are produced concomitantly by human coronary arteryinfiltrating $\mathrm{T}$ cells and act synergistically on vascular smooth muscle cells. Circulation, 119: 1424-1432, 2009.

31. Liu Z, Liu F, Pan H: Correlation of peripheral Th17 cells and Th17-associated cytokines to the severity of carotid artery plaque and its clinical implication. Atherosclerosis, 221: 232241, 2012.

32. Jager A, Kuchroo,VK: Effector and regulatory T-cell subsets in autoimmunity and tissue inflammation. Scand J Immunol, 72: $173-184,2010$.

33. George J: Mechanism of disease: the evolving role of regulatory $\mathrm{T}$ cells in atherosclerosis. Nat Clin Pract Cardiovasc Med, 5: 531-540, 2008.

34. Afzali B, Mitchell P, Lechler RJ, John S, Lombardi G: Translational mini-review series on Th17 cells: induction of interleukin-17 production by regulatory T-cells. Clin Exp Immunol, 159: 120-130, 2010.

35. Singh K, Gatzka M, Peters T, Borkner L, Hainzl A, Wang H, Sindrelaru A, Scharffetter-Kochanek K: Reduced CD18 levels drive regulatory $\mathrm{T}$ cell conversion into Th17 cells in the CD18hypo PL/J mouse model of Psoriasis. J Immunol, 190: 2544-2553, 2013.

36. Okui T, Aoki Y, Ito H, Honda T, Yamazaki K: The presence of IL-17 ${ }^{+} /$Foxp $^{+}$double-positive cells in periodontitis. J Dent Res, 91: 574-579, 2012.

37. Huang G, Wang Y, Chi H: Regulation of Th17 cell differentiation by innate immune signals. Cell Mol Immunol 9: 287-295, 2012.

38. Geddes K, Rubino SJ, Magalhaes JG, Streutker C, Bourhis LL, Cho JH, Robertson SJ, Kim CJ, Kaul R, Philpott DJ, Girardin SE: Identification of an innate $\mathrm{T}$ helper type 17 response to intestinal bacterial pathogens. Nat Med, 17: 837-844, 2011. 